\title{
QUEM TEM MEDO DA CHINA? ANÁLISE E IMPLICAÇÕES PARA OS PRINCIPAIS ESTADOS BRASILEIROS*
}

\section{Gilberto Libânio ${ }^{a}$}

RESUMO: Este trabalho busca examinar os impactos da expansão da China no comércio mundial sobre os estados brasileiros. A principal hipótese considerada aqui é que tais impactos variam de acordo com o padrão de especialização produtiva e comercial dos diversos estados. Neste sentido, regiões exportadoras de produtos primários teriam sido as mais beneficiadas pela expansão chinesa e a consequente elevação da demanda e dos preços internacionais de commodities ao longo da última década, ao passo que estados produtores e exportadores de bens manufaturados tenderiam a sofrer mais fortemente a concorrência da China, tanto no mercado internacional quanto no doméstico. Para avaliar tal questão, o perfil exportador dos principais estados brasileiros foi analisado, e as exportações estaduais foram classificadas de acordo com seu conteúdo tecnológico. Utilizando tal classificação, foram construídos índices de qualidade das exportações para cada estado estudado. Além disso, o perfil exportador dos estados foi avaliado em comparação ao da China, calculando-se os coeficientes de especialização para cada estado em relação à China, e foi analisada a correlação entre esses coeficientes e as taxas de crescimento econômico estadual durante o período 1996-2009. Os resultados sugerem que o crescimento econômico dos estados brasileiros no período recente foi influenciado positivamente pela complementaridade em relação à pauta de exportações da China, devido a sua demanda crescente por commodities agrícolas e minerais. Assim, os estados produtores e exportadores de matérias-primas tenderam a crescer acima da média nacional no período.

PALAVRAS-CHAVE: Crescimento econômico; inserção externa; exportações; China.

CLASSIFICAÇÃO JEL: $\mathrm{O} 11$.

\footnotetext{
* Artigo recebido em 20/05/2012 e aprovado em 06/08/2012.

${ }^{a}$ Doutor em Economia pela University of Notre Dame e professor do Centro de Desenvolvimento e Planejamento Regional de Minas Gerais, da Universidade Federal de Minas Gerais (CEDEPLAR/UFMG). Contato: gilberto@cedeplar.ufmg.br.
} 


\section{WHO'S AFRAID OF CHINA: ANALYSIS AND IMPLICATIONS FOR THE MAJOR BRAZILIAN STATES}

ABSTRACT: This paper examines the impacts of China's expansion in international trade on Brazilian states. The main hypothesis of the study is that such impacts vary according to the pattern of trade specialization of the several states. In this case, commodity-export regions would have benefited the most from the Chinese expansion and the consequent raise in international demand and prices of commodities in the 2000s, whereas producers and exporters of manufactured goods would tend to face competition with China, both in domestic and international markets. In order to address this issue, the export profile of the main Brazilian states was analyzed, and exports were classified according to their technological content. Based on this classification, we built indexes of export quality for each state. In addition, the pattern of export specialization of Brazilian states was analyzed in comparison to the one of China. We calculated coefficients of specialization for each state in relation to China, and investigated the correlation between these coefficients and economic growth rates for the period of 1996-2009. Results suggest that economic growth in Brazilian states has been strongly influenced by the degree of complementarity in relation to the Chinese exports, and its growing demand for agricultural and mineral commodities. Thus, states which produce and export raw materials tended to grow above the national average between 2000 and 2009.

KEYWORDS: Economic growth; exports; China. 


\section{INTRODUÇÃO}

A China tem se tornado um dos grandes destaques no cenário econômico global nos últimos anos em virtude de suas expressivas taxas de crescimento e de seu peso crescente no comércio internacional. $\mathrm{O}$ crescimento da importância desse país decorre não apenas de seu desempenho, mas também do seu porte: o país tem a maior população do planeta e, atualmente, a segunda maior economia, com um PIB de aproximadamente US\$ 6 trilhões (em 2010). Ademais, já ocupa o segundo lugar em termos de volume de comércio internacional, com cerca de $10 \%$ do total transacionado mundialmente. Essas características fazem com que o crescimento chinês tenha implicações e impactos globais bastante distintos de outras experiências bem-sucedidas de crescimento econômico na segunda metade do século XX, como no caso do Japão, da Coreia do Sul e de outros "tigres asiáticos".

O crescimento chinês e sua presença maciça no comércio internacional têm causado intensa preocupação e impactos diferenciados sobre as economias de países desenvolvidos e em desenvolvimento. Tais impactos podem ser resumidos em duas frentes. Por um lado, a grande competitividade dos produtos manufaturados chineses no mercado mundial representa um desafio e uma ameaça a países cuja pauta de exportações seja baseada neste tipo de produto. Por outro, a expressiva demanda da China por commodities tem provocado substancial elevação de seus preços no mercado internacional e beneficiado países exportadores de produtos primários. Em última instância, os efeitos da expansão chinesa dependem do padrão de especialização setorial das economias, sendo que os países mais penalizados são aqueles cujas estruturas produtivas competem diretamente com a China no comércio mundial.

O presente artigo busca analisar os impactos da expansão da China no comércio mundial sobre os principais estados exportadores brasileiros. A principal hipótese é que tais impactos variam de acordo com o padrão de especialização produtiva e comercial dos diversos estados. Nesse sentido, poder-se-ia argumentar que regiões exportadoras de commodities foram as mais beneficiadas pela elevação da demanda e dos preços internacionais ao longo da década.

Tal resultado pode ser confirmado pela variável “destino das exportações”. Quando se compara os dois principais parceiros comerciais do Brasil - China e EUA -, fica claro que a economia chinesa obteve trajetória de crescimento mais elevada, portanto expandiu mais fortemente sua demanda por importações. Assim, os estados brasileiros cujas exportações são mais concentradas para o mercado chinês tendem a ter trajetória mais expressiva de crescimento das exportações.

Para responder a essas questões, o artigo analisa o perfil exportador dos maiores estados brasileiros, e classifica as exportações estaduais de acordo com seu conteúdo 
tecnológico, seguindo a classificação em cinco grupos proposta por Lall (2000): produtos primários, manufaturas baseadas em recursos naturais e manufaturas de baixa, média e alta tecnologias.

Além disso, é também analisado o papel desempenhado pelo comércio BrasilChina, ou seja, avalia-se o perfil exportador dos estados brasileiros em comparação ao da China. São calculados os coeficientes de especialização (Blazquez-Lidoy et al., 2006) para os principais estados exportadores em relação àquele país, e analisa-se a correlação entre esses coeficientes e as taxas de crescimento econômico estadual durante o período.

O presente estudo aborda várias questões pouco exploradas. Algumas de suas principais contribuições são a análise dos padrões de especialização em nível subnacional, e sua relevância para a performance recente das economias. Por outro lado, embora a classificação proposta por Lall (2000) tenha sido aplicada para vários países, ainda não há estudos similares na literatura a respeito de perfil exportador de estados e regiões do Brasil. Da mesma forma, a metodologia proposta por Blazquez-Lidoy et al. (2006) é aqui aplicada em nível subnacional, com ênfase no papel da China como parceiro comercial. Assim, a análise das especificidades regionais decorrentes da evolução da economia mundial, com ênfase nos impactos da expansão chinesa, é a principal contribuição original do estudo proposto.

O presente artigo está organizado em seis seções, além desta introdução. Na próxima seção, apresenta-se de forma resumida o marco teórico que dá suporte ao trabalho, associado a uma visão kaldoriana e schumpeteriana da relação entre exportações, especialização produtiva e crescimento econômico. A seção três discute de forma sucinta a expansão chinesa no cenário econômico mundial. Na seção quatro, são apresentados a metodologia e os dados utilizados. Em seguida, descreve-se o perfil exportador dos maiores estados brasileiros no período 1996-2010, levando em consideração o conteúdo tecnológico da pauta, assim como os índices de competição em exportações frente à China. Na seção seis, são avaliados os efeitos imediatos da crise de 2008 sobre as exportações estaduais e analisa-se a relação entre estrutura produtiva e crescimento econômico por meio de medidas simples de correlação para o período 1996-2009. A seção sete encerra o artigo com algumas considerações finais.

\section{PADRÃO DE ESPECIALIZAÇÃO E CRESCIMENTO ECONÔMICO}

Do ponto de vista teórico, o ponto de partida da pesquisa é a discussão presente na literatura a respeito da relação entre os padrões de especialização na economia, em particular o papel do setor manufatureiro, e o crescimento econômico a longo prazo. 
Correntes teóricas de inspiração schumpeteriana e kaldoriana têm abordado essa temática e servem como referencial teórico para o presente artigo.

No primeiro grupo, o foco recai sobre a importância dos mecanismos de geração e difusão da inovação tecnológica para o crescimento e desenvolvimento econômicos. Em geral, concebe-se que diferenças internacionais nos níveis de renda per capita são explicadas por diferenças tecnológicas e de capacidades inovadoras entre os países. Ademais, considera-se que tais diferenças não são facilmente superáveis, uma vez que há vários fatores que retardam ou dificultam a difusão da informação entre países, como a existência de patentes, informação imperfeita, escassez de infraestrutura cientifica e tecnológica, e a própria dificuldade de adaptação e absorção de novos produtos ou processos por parte das firmas (Dosi et al., 1990; Fagerberg, 1994).

Sob a perspectiva schumpeteriana, processos de catch up são parte importante da dinâmica de desenvolvimento dos países, e são possíveis em decorrência de mecanismos de imitação, learning by doing, engenharia reversa, incorporação de tecnologias via importação de bens de capital, entre outros. Nesse caso, argumenta-se que o processo de imitação de tecnologias já existentes representa uma via alternativa de desenvolvimento para os países tecnologicamente mais atrasados, de modo que eles não dependam exclusivamente de sua capacidade inovativa - como é o caso dos países líderes -, mas também de seu desempenho como imitador. Como o custo relativo da absorção de tecnologias já existentes seria inferior ao da geração de novas tecnologias, os países atrasados tenderiam a apresentar maiores taxas de crescimento da produtividade, o que garantiria a ocorrência de catching up.

Cabe notar que, em tese, o ritmo de avanço tecnológico e de ganhos de produtividade será mais acelerado quanto mais distante um país estiver da fronteira tecnológica. Isso significa que o potencial de crescimento dos países atrasados tende a se reduzir à medida que esses países avançam na incorporação de novas tecnologias dos países lideres, reduzindo o hiato tecnológico em relação a estes. Entretanto, a eficiência na imitação e absorção de novas tecnologias depende de características estruturais e institucionais dos países, que não são garantidas exclusivamente por seu atraso relativo. Ou seja, a mera ocorrência de atraso tecnológico não garante a incorporação eficiente de tecnologias e, portanto, é necessária a criação de condições adequadas para tanto, associadas principalmente à qualificação da mão de obra e à existência de instituições de pesquisa.

Segundo a perspectiva schumpeteriana, portanto, relação entre especialização produtiva e crescimento econômico passa pela capacidade diferenciada de geração e absorção de tecnologias. Assim, diferentes estruturas produtivas trazem consigo diferentes implicações para o crescimento a longo prazo, pois representam diferentes possibilidades de inovação, diferenciação e aprendizado. 
O segundo referencial teórico deste artigo parte dos trabalhos de Kaldor (1966, $1970)^{1}$. Nesse caso, a hipótese inicial é de que o setor industrial é o "motor" do crescimento econômico, devido à existência de elevadas economias de escala nesse setor e de sua importância na geração e propagação de progresso tecnológico. Ademais, argumenta-se que as características intrínsecas do setor industrial conduzem as economias nas quais o setor se expande a ganhos de competitividade internacional, o que leva a maior geração de demanda via exportações e menores restrições externas ao crescimento.

Em linhas gerais, o argumento kaldoriano se baseia na ideia de que o crescimento da economia é limitado fundamentalmente pelo crescimento da demanda agregada, e, particularmente, pelo crescimento das exportações, que são consideradas o principal componente verdadeiramente autônomo da demanda. Assim, o crescimento das exportações alimenta a demanda necessária à expansão da produção, que, por sua vez, leva a ganhos de produtividade em virtude da ocorrência de retornos crescentes de escala, particularmente no setor manufatureiro. Sob determinadas condições, tais ganhos de produtividade permitem queda dos custos salariais e, dada uma margem de lucro constante, redução dos preços, elevando a competitividade internacional da economia em questão e possibilitando nova expansão das exportações, o que realimenta esse ciclo virtuoso de forma cumulativa. Desse modo, uma vez que um país ou uma região adquira alguma vantagem em termos de crescimento, tende a conservá-la devido ao processo de retornos crescentes e os consequentes ganhos de competitividade que o crescimento induz ${ }^{2}$.

Kaldor afirma, no entanto, que a presença de retornos de escala estáticos e dinâmicos - captados pelo coeficiente de Verdoorn - não é distribuída de forma homogênea entre setores da economia, sendo particularmente relevante no caso do setor manufatureiro. Assim sendo, economias cuja participação do setor industrial é mais expressiva tenderiam a obter melhor desempenho em termos de crescimento de longo prazo, segundo a dinâmica do modelo, em virtude de ganhos mais expressivos de produtividade causados por retornos de escala mais elevados (Ros, 2002).

Em resumo, os padrões de especialização produtiva e o perfil exportador de países e regiões apresentam implicações fundamentais no que se refere à dinâmica de crescimento de longo prazo das economias, posto que os diversos setores e produtos estão associados a diferentes elasticidades-renda da demanda por exportações, diferentes graus de retornos de escala e diferentes possibilidades de inovação tecnológica e aprendizado. Por isso, é crucial examinar as estruturas produtivas e exportadoras de países e regiões, bem como sua evolução ao longo do tempo.

\footnotetext{
${ }^{1}$ Ver também Young (1928) para uma discussão pioneira sobre a relação entre expansão dos mercados e ganhos de produtividade na indústria.

${ }^{2}$ Ver Dixon and Thirlwall (1975), para um modelo canônico de crescimento liderado pelas exportações em uma perspectiva kaldoriana.
} 


\section{A CHINA NO CENÁRIO ECONÔMICO INTERNACIONAL}

A economia chinesa tem crescido a uma taxa média anual de $10 \%$ nas últimas três décadas. Esse expressivo crescimento tem sido baseado fundamentalmente no dinamismo do setor industrial, que cresceu 32 vezes entre 1978 e 2010, o que corresponde a uma taxa média de crescimento de quase 12\% ao ano. Em 2010, observa-se que o setor secundário é de fato o mais importante da economia da China, representando quase $50 \%$ do produto interno bruto (PIB) ${ }^{3}$.

Por outro lado, o país tem passado por um processo de abertura comercial, com declínio nas tarifas médias de importação a partir dos anos 1990, e elevado substancialmente sua participação no comércio internacional nos últimos anos. A inclusão da China na Organização Mundial do Comércio (OMC) a partir de 2001 reflete sua maior abertura comercial e também contribuiu para alavancar sua inserção como potência comercial global ao permitir maior acesso de produtos chineses nos mercados internacionais. Entre 2002 e 2008, o volume de exportações da China cresceu a uma média anual de $24 \%$, enquanto o volume de importações cresceu em média $22 \%$ ao ano. Assim, sua participação nas exportações mundiais tem crescido consistentemente ao longo do tempo, passando de 1,5\%, em 1980, para 2,5\% em 1995, e atingindo $7 \%$, em 2005, e 10\% em 2010.

A expansão da China nos mercados mundiais e sua maior abertura comercial tiveram também como consequência um aumento das exportações e importações como proporção do PIB. Em 2008, as exportações corresponderam a 32\% do PIB, enquanto as importações alcançaram $25 \%$ do PIB. Esses valores colocam a China como uma economia com elevado grau de abertura comercial (57\%), principalmente se comparada a outros países de dimensão continental, como Brasil, Estados Unidos e Canadá, cujos fluxos comerciais (exportações mais importações) correspondem a menos de $30 \%$ do PIB.

Cabe notar que os dois elementos destacados acima - expressivo crescimento do setor manufatureiro e expansão do comércio internacional - não são independentes. Durante os últimos anos, quase $90 \%$ das exportações da China concentram-se em três setores industriais: equipamento e material de transporte, bens manufaturados e outras manufaturas. Suas importações são também baseadas nestes setores, embora, nos últimos cinco anos, tem-se observado crescente participação de combustíveis e lubrificantes, bem como de produtos primários em geral. Dado o expressivo crescimento de setores intensivos em commodities, a China tem sido a principal responsável pela

\footnotetext{
${ }^{3}$ Por sua vez, os setores primário e terciário correspondem, respectivamente, a $10 \%$ e $43 \%$ do PIB.
} 
expansão da demanda mundial por produtos como minério de ferro, petróleo, cobre e soja, o que tem beneficiado países exportadores de matérias-primas, tanto pelo aumento dos volumes exportados, quanto pela elevação generalizada dos preços de commodities no mercado internacional.

A expansão da China tem contribuído não apenas para elevar os preços das commodities, mas também para o declínio nos preços de manufaturas, gerando, uma vez mais, uma dinâmica de termos de troca desfavorável a países cuja pauta de exportação seja concentrada em manufaturas (UNCTAD, 2009).

O crescimento chinês e sua presença maciça no comércio internacional têm causado grande interesse no que se refere a seus impactos sobre outras economias emergentes. Particularmente, cabe destacar os impactos da expansão chinesa sobre os países da América Latina, que têm sido objeto de diversos trabalhos recentes (Blazquez-Lidoy et al., 2006; Jenkins et al., 2008; Lall and Weiss, 2005; Mesquita Moreira, 2007). Em linhas gerais, tais efeitos dependem do padrão de especialização setorial das economias, sendo que os países mais beneficiados são aqueles cujas estruturas produtivas não competem diretamente com a China no comércio mundial.

Para os países da América Latina, observa-se grande diversidade em relação a esses indicadores. Em um extremo, encontra-se o México, com um elevado grau de competição com a China, devido principalmente às exportações de manufaturas para o mercado norte-americano. Em outro extremo, temos países como Paraguai, Venezuela, Bolívia e Chile, cujas pautas de exportação são mais fortemente concentradas em commodities agrícolas ou minerais e que, portanto, apresentam padrão de especialização bastante distinto em relação à China. De modo geral, a situação da maioria dos países da América Latina é relativamente favorável, sugerindo que a expansão chinesa tende a trazer mais benefícios do que custos para a região como um todo.

Quanto ao Brasil, sua posição é intermediária. Assim sendo, ele poderia ser incluído no grupo de países cuja competição com a China não é tão alta, mas ainda assim preocupante. Tal resultado decorre do fato de que nossa pauta de exportação é caracterizada por elevado grau de diversificação, com presença importante tanto de manufaturas quanto de commodities.

De modo geral, a experiência recente mostra que o Brasil tem sido beneficiado pela expansão da China no cenário mundial. As exportações brasileiras para aquele país cresceram quase trinta vezes ao longo da última década, passando de U\$ 1,1 bilhão, em 2000, para U\$ 30,8 bilhões em 2010 (15\% do total).

Quando se avalia a evolução recente da economia brasileira segundo setores de atividade, observa-se que seu crescimento nos últimos anos tem sido puxado principalmente pelo setor agropecuário e pela indústria extrativa mineral, enquanto que o setor industrial como um todo tem crescido abaixo da média global da economia. Por 
outro lado, alguns setores da indústria têm sido particularmente mais afetados pela concorrência com produtos chineses, tanto pela competição no mercado doméstico quanto pela ameaça a mercados de exportação.

\section{BASE DE DADOS E METODOLOGIA}

Este trabalho busca investigar os impactos da expansão da China no comércio mundial sobre os principais estados exportadores brasileiros, a partir de seu padrão de especialização comercial, e procura discutir as implicações de tal perfil para a dinâmica de crescimento das economias estaduais no período recente. Frente a este objetivo, os principais produtos derivados desta pesquisa são: (i) uma descrição detalhada do perfil exportador dos principais estados brasileiros no período 1996-2010, seguindo a classificação proposta por Lall (2000); (ii) a construção de índices de qualidade das exportações estaduais; (iii) a estimação dos coeficientes de especialização de acordo com a metodologia proposta por Blazquez-Lidoy et al. (2006) para os maiores estados exportadores em relação a China; (iv) uma análise das relações entre o padrão de especialização comercial, a participação da China nas exportações estaduais e o desempenho econômico dos estados.

Em relação ao item (i), os dados de exportação por estado foram classificados em cinco grupos, a saber: produtos primários, manufaturas baseadas em recursos naturais e manufaturas de baixa, média e alta tecnologia 4 .

A partir dessa classificação, propõe-se aqui a construção de índices de qualidade das exportações (Qit) para os principais estados do Brasil (i), calculado ano a ano $(t)$, entre 1996 e 2010, de acordo com a seguinte expressão:

$$
Q_{i t}=\frac{X_{2 i t}-X_{1 i t}}{X_{i t}}
$$

Duas especificações alternativas foram propostas para tal índice. A primeira especificação é inspirada na abordagem schumpeteriana e busca enfatizar o conteúdo tecnológico das exportações. Nesse caso, $X_{2 i t}$ corresponde à soma das exportações de manufaturas de média (MT) e alta tecnologia $(\mathrm{HT}), X_{1 i t}$ representa a soma das exportações de produtos primários (PP), manufaturas baseadas em recursos naturais (RB) e de baixa tecnologia (LT), e $X_{i t}$ corresponde ao total exportado. Cabe notar que esse índice, aqui denominado $Q S_{i t}$, assume valores entre -1 e +1 e que valores negativos indicam predominância de produtos de baixo conteúdo tecnológico na pauta exportadora de um estado.

\footnotetext{
${ }^{4}$ Ver Lall (2000) para descrição detalhada de cada um dos grupos.
} 
A segunda especificação é inspirada em Kaldor - e a proposição de que o setor manufatureiro tem papel crucial para o crescimento - e, por isso, distingue entre bens manufaturados e produtos ligados a recursos naturais. Nesse caso, $X_{2 i t}$ corresponde à soma das exportações de manufaturas em geral, englobando baixa (LT), média (MT) e alta tecnologia (HT), $X_{1 i t}$ representa a soma das exportações de produtos primários (PP) e manufaturas baseadas em recursos naturais (RB), e $X_{i t}$ corresponde ao total exportado. Também nesta especificação, em que será denominado $Q K_{i t}$, óndice de qualidade das exportações assume valores entre -1 e +1 , e valores negativos sugerem a prevalência de produtos de base natural no total das exportações estaduais.

Tanto na especificação dita schumpeteriana quanto na kaldoriana, quanto maior o valor observado para os índices, maior a qualidade da pauta exportadora, segundo o critério de conteúdo tecnológico utilizado na classificação proposta por Lall (2000). Cabe ainda notar que, no caso de alguns dos estados, as duas especificações tendem a apresentar valores muito próximos. Como a única diferença entre QSit e QKit consiste no posicionamento do percentual de exportações de manufaturas de baixa tecnologia na fórmula do índice, as duas especificações gerarão valores similares nos estados em que esse tipo de produto tenha pequena relevância na pauta exportadora.

Os coeficientes de especialização, por sua vez, baseiam-se em Blazquez-Lidoy et al. (2006), que propõem um método para calcular o grau de similitude entre os padrões de especialização de dois países ou duas regiões. O chamado "índice de competição em exportações" (CI) corresponde à média aritmética de dois outros índices: (i) coeficiente de especialização (CS); e (ii) coeficiente de conformidade (CC), definidos como:

$$
\begin{gathered}
C S=1-\frac{1}{2} \sum_{n}\left|a_{i t}^{n}-a_{j t}^{n}\right| \\
C C=\frac{\sum_{n} a_{i t}^{n} a_{j t}^{n}}{\sqrt{\sum_{n}\left(a_{i t}^{n}\right)^{2} \sum_{n}\left(a_{j t}^{n}\right)^{2}}}
\end{gathered}
$$

onde $a_{i t}$ e $a_{j t}$ representam a participação do produto $n$ no total exportado pelo país ou pela região $i$ e $j$, respectivamente, no período $t$. Para os propósitos deste estudo, o país $i$ seria a China e $j$ seriam os estados brasileiros. Se dois países ou duas regiões tiverem a mesma pauta de exportação, os índices CS e CC serão iguais a 1. No extremo oposto, se não há nenhuma similaridade entre as pautas de exportação de duas regiões, os coeficientes seriam iguais a zero. No primeiro caso, portanto, a competição por mercados externos seria acirrada entre as duas regiões, enquanto que, no segundo caso, não haveria competição, e sim complementaridade entre duas economias. 
Por fim, o artigo examina a correlação entre os índices de qualidade das exportações dos estados, bem como os seus índices de competição em exportações em relação à China e a performance econômica dos estados.

Os dados de exportação são provenientes do Sistema Alice, do MDIC, e descrevem as exportações estaduais desagregadas por subsetores para o período 1996-2010. Como tais exportações são desagregadas segundo a Nomenclatura Comum do MERCOSUL (NCM) e a classificação proposta por Lall (2000) se baseia em uma desagregação segundo o Standard International Trade Classification (SITC) a três dígitos, procedeu-se a uma conversão entre as duas classificações para possibilitar a agregação em cinco grupos proposta por Lall (2000).

Os dados de exportação da China, utilizados na construção dos índices de competição em exportações, são provenientes do Intracen. Já os usados para medir o crescimento econômico dos estados provêm da série de PIB estadual - valor adicionado a preços constantes - do Instituto Brasileiro de Geografia e Estatística (IBGE), para o período de 1996-2009.

\section{O PERFIL EXPORTADOR DOS ESTADOS BRASILEIROS (1996-2010)}

\subsection{EXPORTAÇÕES TOTAIS E POR CLASSIFICAÇÃO TECNOLÓGICA}

As exportações do Brasil tiveram expressivo crescimento na última década, particularmente entre 2002 e 2008, acompanhando a tendência registrada em nível mundial. Impulsionadas principalmente pela expansão da demanda e dos preços de commodities agrícolas e minerais, as exportações saíram de um patamar em torno de U $\$ 50$ bilhões, no ano 2000, e atingiram um pico de quase U\$ 200 bilhões em 2008. Devido à crise financeira internacional e à consequente desaceleração da economia mundial em 2009, as exportações brasileiras observaram um declínio acentuado de aproximadamente $30 \%$, caindo abaixo de U\$ 150 bilhões em 2009. No ano seguinte, verifica-se recuperação das vendas externas, que voltaram aos níveis pré-crise, atingindo novamente cerca de U\$ 200 bilhões em 2010, o que corresponde a cerca de 11\% do PIB.

A distribuição regional das exportações brasileiras indica elevado grau de concentração na região Sudeste, responsável por pouco menos de $60 \%$ do total exportado. Por sua vez, a distribuição das exportações por unidade da federação mostra que apenas seis estados são responsáveis por três quartos do total exportado pelo Brasil: São Paulo (SP), Minas Gerais (MG), Rio de Janeiro (RJ), Rio Grande do Sul (RS), Paraná (PR), Pará (PA). A análise desenvolvida neste artigo vai se concentrar nestes seis estados, não apenas pelo seu peso no total das exportações brasileiras, mas também por sua representatividade no PIB - cerca de dois terços. 
Os dados de exportação do Brasil foram aqui classificados segundo o conteúdo tecnológico, a partir da metodologia proposta por Lall (2000). Observa-se que as exportações de produtos de base natural - produtos primários e manufaturas baseadas em recursos naturais - ocupam posição de destaque, e correspondem a mais de dois terços do total exportado (Gráfico 1).

Cabe notar, entretanto, que existe grande heterogeneidade entre as regiões do Brasil no que se refere ao conteúdo tecnológico das exportações. Em particular, verifica-se que as regiões Sudeste e Sul apresentam a pauta mais diversificada e com maior peso das exportações de produtos manufaturados de alta, média e baixa tecnologia. As regiões Nordeste e Norte, por sua vez, têm nas manufaturas baseadas em recursos naturais seu principal item de exportação. Por fim, a região Centro-oeste - importante fronteira agrícola do país - concentra $80 \%$ de suas vendas externas em produtos primários (Gráfico 2).

Outro dado importante diz respeito à evolução das exportações por classificação tecnológica no período recente. Observa-se, ao longo da ultima década (2000-2010), que a participação de produtos de base natural na pauta exportadora brasileira apresentou significativa elevação, partindo de valores próximos a 50\% no final dos anos 1990 e atingindo percentual de aproximadamente 70\% no final dos anos 2000 . Esse resultado sugere que o expressivo crescimento no volume total exportado pelo país nos últimos anos foi acompanhado por uma alteração importante em sua estrutura produtiva e exportadora, consolidando um perfil primário-exportador em detrimento da exportação de manufaturas. Tal reprimarização da pauta exportadora se reflete no declínio (de 20 p.p.) da participação de manufaturas no total exportado,

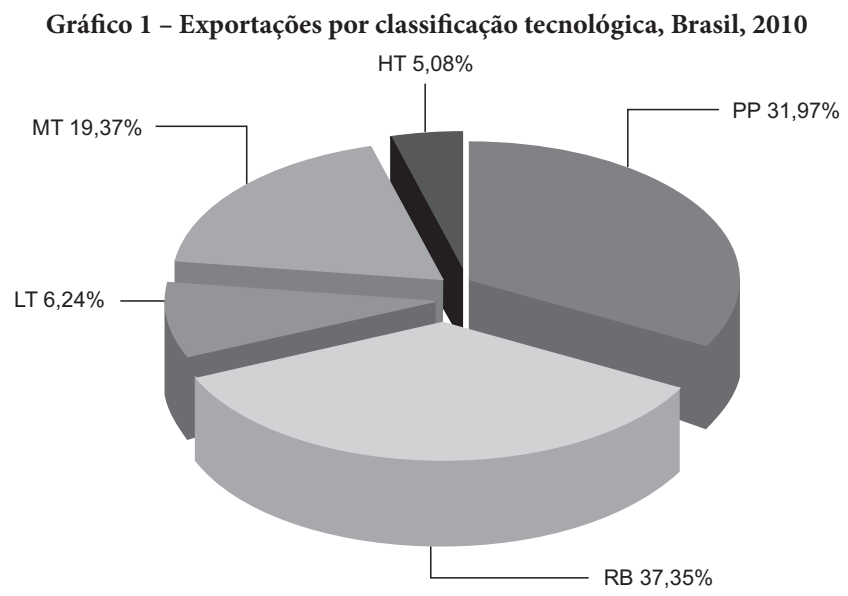

Fonte: Elaboração própria com base em dados de MDIC (2011). 
Gráfico 2 - Exportações por classificação tecnológica, regiões do Brasil, 2010

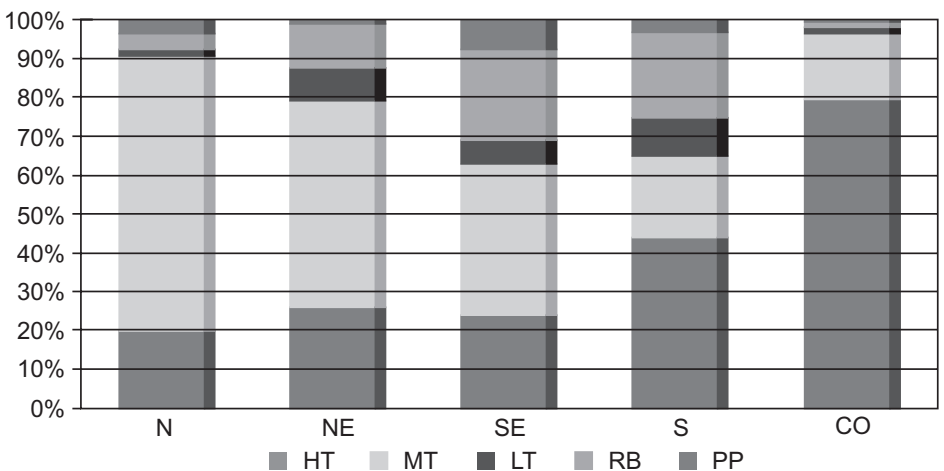

Fonte: Elaboração própria com base em dados de MDIC (2011).

distribuído homogeneamente entre os grupos de baixa, média e alta tecnologia. O Gráfico 3 ilustra a evolução dos totais exportados segundo classificação tecnológica entre 1996 e 2010.

As exportações dos seis estados mencionados anteriormente foram também classificadas e analisadas segundo seus valores tot ais e seu conteúdo tecnológico.

No caso de São Paulo, principal estado exportador do Brasil, as exportações estaduais praticamente triplicaram entre 2000 e 2010, passando de U\$ 19 bilhões para U\$ 51 bilhões, aproximadamente (Gráfico 4). Em 2009, em consequência da crise internacional, as exportações de São Paulo declinaram cerca de 40\%, observandose uma recuperação parcial no ano seguinte, quando as vendas externas do estado cresceram $31 \%$.

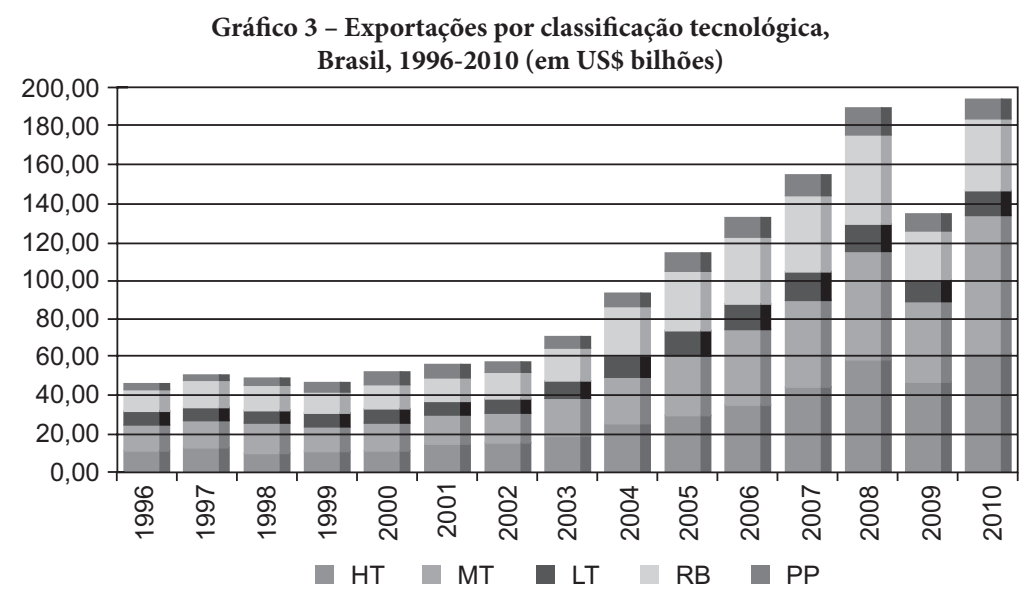

Fonte: Elaboração própria com base em dados de MDIC (2011). 
Gráfico 4 - Exportações por classificação tecnológica,

São Paulo, 1996-2010 (em US\$ bilhões)

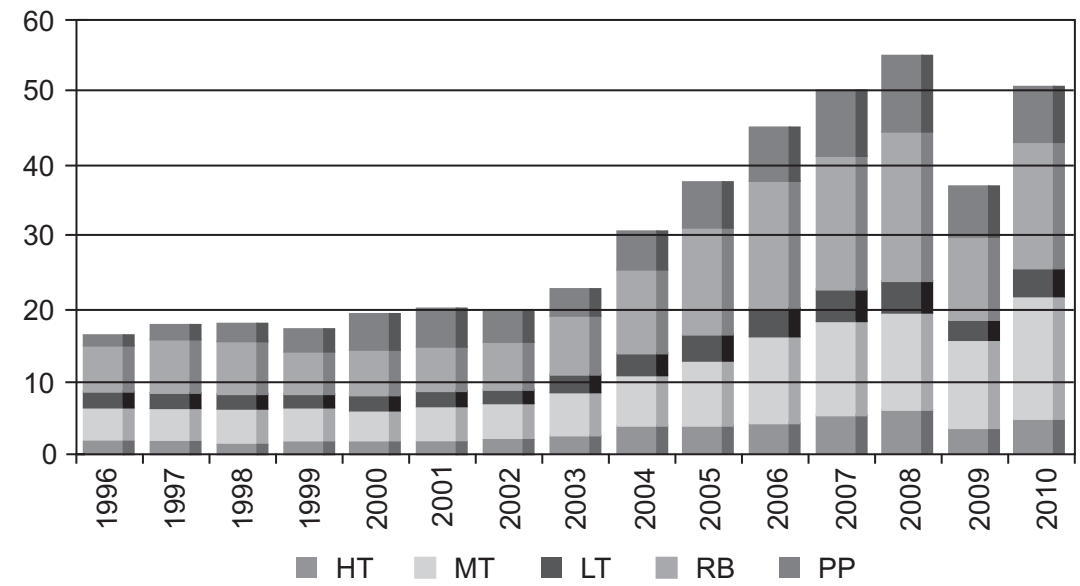

Fonte: Elaboração própria com base em dados de MDIC (2011).

Como esperado, verifica-se que o estado de São Paulo apresenta a pauta de exportações mais diversificada do Brasil, pois concentra a maior parte do parque industrial nacional. De fato, São Paulo é o único dentre os maiores estados exportadores cuja pauta não é composta majoritariamente por produtos de base natural ${ }^{5}$. Durante todo o período analisado, a categoria de manufaturas de baixa, média e alta tecnologia concentrou quase dois terços do total exportado pelo estado, com destaque para os setores automobilístico, aeronáutico, de máquinas e equipamentos, e de produtos eletrônicos. No grupo de produtos de base natural, destacam-se as exportações de açúcar e álcool, carnes, e do complexo de soja, entre outros.

Minas Gerais é o segundo maior exportador do Brasil, e suas vendas externas atingiram cerca de U\$ 30 bilhões em 2010, valor cinco vezes maior do que o observado no início dos anos 2000, quando as exportações mineiras eram de aproximadamente U\$ 6 bilhões. Cabe notar que tal crescimento está acima da média nacional no período, o que fez com que o estado ganhasse participação relativa no total das exportações do Brasil ao longo da década. Acompanhando a tendência nacional, as exportações de Minas Gerais tiveram declínio acentuado - acima de 30\% - em 2009, mas observaram forte recuperação em 2010, superando em mais de U\$ 6 bilhões o valor exportado antes da crise.

\footnotetext{
${ }^{5} \mathrm{O}$ estado do Amazonas também tem essa característica, com cerca de $50 \%$ de sua pauta exportadora composta por produtos de alta tecnologia - em consequência da presença da Zona Franca de Manaus. No entanto, a participação do estado no total de exportações do Brasil foi de apenas 0,6\% em 2010.
} 
No que se referem à composição da pauta, as exportações do estado de Minas Gerais são lideradas por manufaturas baseadas em recursos naturais - principalmente minério de ferro - e produtos primários - com destaque para o café. Outros setores relevantes na pauta de exportações do estado são o automobilístico (particularmente pela presença da FIAT Automóveis) e o complexo siderúrgico-metalúrgico. Ao longo dos anos 2000, observou-se um agravamento da concentração da pauta, com o aumento gradual das exportações de minério de ferro, principalmente a partir de 2003. Em 2010, o minério de ferro respondeu por mais de $40 \%$ das exportações estaduais, e liderou a recuperação das exportações mineiras após a crise de 2009.

Cabe notar que a China desempenha um papel central nessa evolução, pois o país é o principal destino das vendas externas de Minas Gerais, com participação de aproximadamente $30 \%$ em 2010, e concentra quase a totalidade das exportações de minério do estado.

A evolução das exportações do estado do Rio de Janeiro apresenta características bem peculiares. Em primeiro lugar, porque o valor de suas vendas externas cresceu muito acima da média nacional: mais de 10 vezes entre 2000 e 2010 - passando de U\$ 1,6 bilhão para U\$ 19 bilhões ao longo da década. Em segundo lugar, porque mais de $80 \%$ desse crescimento é explicado apenas pelas exportações de petróleo.

Em consequência da crise de 2009, as exportações do Rio de Janeiro sofreram a queda mais acentuada entre os principais estados exportadores, com um declínio superior a 40\% em relação ao ano anterior. No entanto, sua recuperação em 2010 foi também uma das mais acentuadas entre os maiores estados, com uma expansão de 50\%.

O caráter particular da pauta de exportações do Rio de Janeiro fica evidente quando se analisa os dados segundo o conteúdo tecnológico. Nesse caso, observa-se que

Gráfico 5 - Exportações por classificação tecnológica, Minas Gerais, 1996-2010 (em US\$ bilhões)

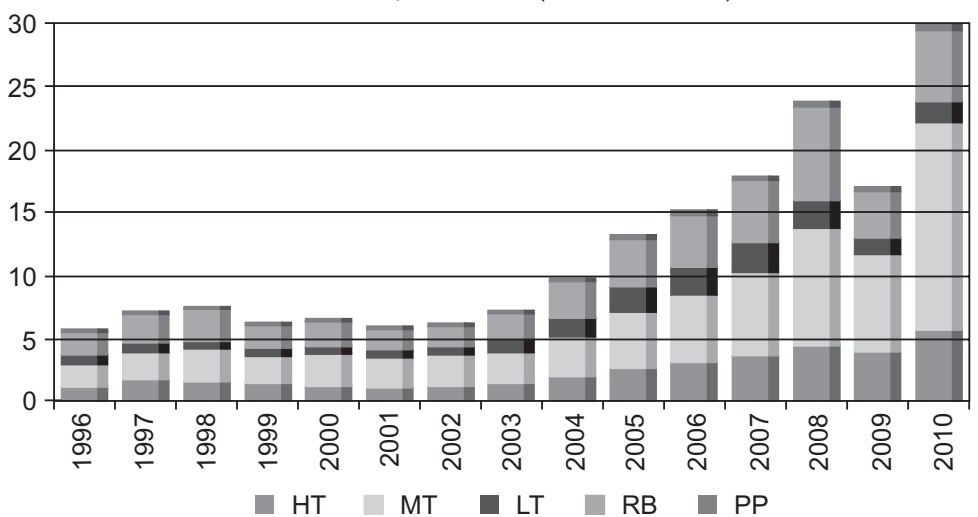

Fonte: Elaboração própria com base em dados de MDIC (2011). 
o atual padrão de especialização foi constituído a partir do início da década passada, quando as exportações de petróleo observaram elevação expressiva e passaram a representar uma proporção cada vez maior das vendas externas do estado. Em 2010, a exportação de produtos primários representou quase $80 \%$ do total exportado pelo Rio de Janeiro (Gráfico 6).

Gráfico 6 - Exportações por classificação tecnológica, Rio de Janeiro, 1996-2010 (em US\$ bilhões)

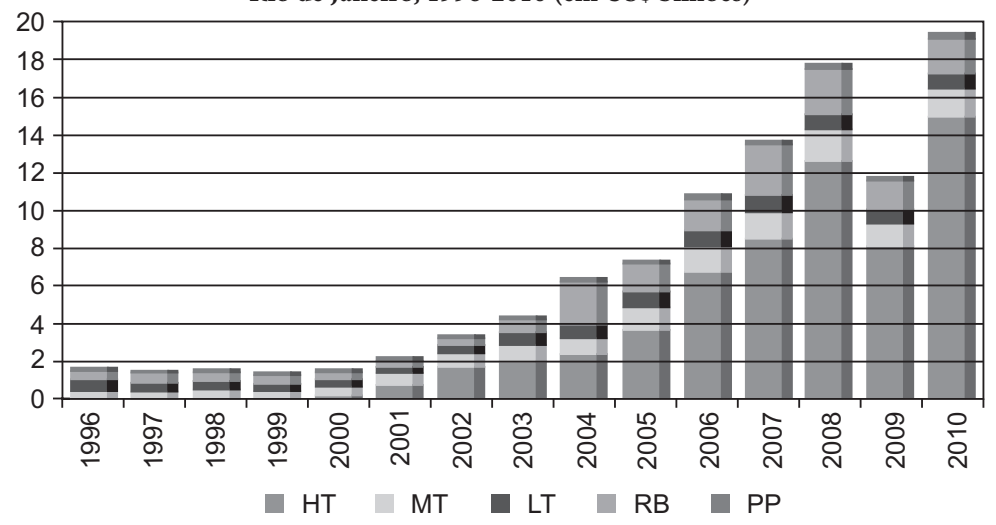

Fonte: Elaboração própria com base em dados de MDIC (2011).

O estado do Rio Grande do Sul é o quarto principal estado exportador do Brasil e o mais importante da região Sul. Crescendo um pouco abaixo da média nacional, o total exportado pelo estado triplicou entre 2000 e 2008, quando atingiu cerca de US\$ 18 bilhões. Em função da crise financeira internacional, o estado apresentou em 2009 um declínio de cerca de 30\% no valor de suas exportações em comparação com o ano anterior. No entanto, o Rio Grande do Sul foi - entre os maiores estados exportadores - um dos que tiveram a menor recuperação percentual nas exportações em 2010 $(13,5 \%)$, o que faz com que os totais exportados nesse ano sejam ainda inferiores aos observados em 2008 (Gráfico 7).

No que se refere ao conteúdo tecnológico das exportações, assim como São Paulo, o Rio Grande do Sul se caracteriza por uma distribuição mais equilibrada entre os diversos grupos de produtos exportados e por uma participação relativamente elevada de manufaturas na pauta exportadora, principalmente de baixa e média tecnologias. Ao longo da última década, no entanto, verifica-se uma participação declinante desses produtos no total exportado (declínio de 10 a 15 pontos percentuais) em favor das exportações de produtos do setor agropecuário - que é o segmento exportador mais tradicional do estado. De fato, a participação dos produtos primários representava cerca de 30\% das exportações estaduais no final dos anos 1990 e foi crescendo paulatinamente até alcançar cerca de 45\% do total em 2010. Desde 2007, os produtos de base 
Gráfico 7 - Exportações por classificação tecnológica, Rio Grande do Sul, 1996-2010 (em US\$ bilhões)

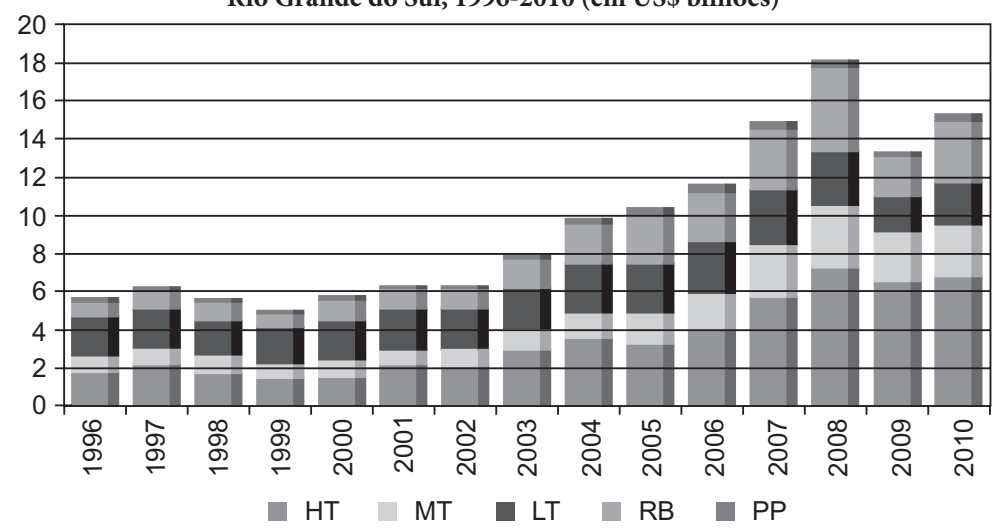

Fonte: Elaboração própria com base em dados de MDIC (2011).

natural (PP e RB) têm participação majoritária no valor das exportações do Rio Grande do Sul. As vendas externas de fumo, carnes e grãos são as principais responsáveis pela participação de produtos primários na pauta exportadora, enquanto que os principais itens de exportação classificados como manufaturas provém do setor automobilístico, de plásticos e maquinário.

O Paraná é o segundo principal estado exportador da região Sul e o quinto mais importante do Brasil, com participação de pouco mais de 7\% no total de exportações do país em 2010. O estado também seguiu abaixo a tendência nacional e observou um crescimento de aproximadamente três vezes no valor de suas exportações ao longo da última década, atingindo um pico de quase US\$15 bilhões em 2008. A crise financeira iniciada naquele ano provocou um declínio significativo nas exportações estaduais em 2009, em comparação aos demais estados da região (cerca de 38\%). Assim como no caso do Rio Grande do Sul, a recuperação das vendas externas em 2010 foi insuficiente para que o estado voltasse a atingir o pico de exportações observado em 2008 (Gráfico 8).

Por outro lado, a pauta de exportações do Paraná apresenta participação importante de produtos primários - pouco acima de 40\%, em média, no período 2000-2010 -, com destaque para a exportação de grãos e carne, entre outros. Considerando-se também a relevância das exportações de manufaturas baseadas em recursos naturais, particularmente no setor sucroalcooleiro, o total das exportações estaduais de produtos de base natural representa em média dois terços da pauta. A exportação de produtos manufaturados, por sua vez, representa cerca de um terço do total, principalmente no setor automobilístico. Vale ressaltar que a distribuição das exportações do Paraná entre os cinco grupos propostos por Lall (2000) apresentou relativa estabilidade entre o inicio e o fim dos anos 2000. 
Gráfico 8 - Exportações por classificação tecnológica,

Paraná, 1996-2010 (em US\$ bilhões)

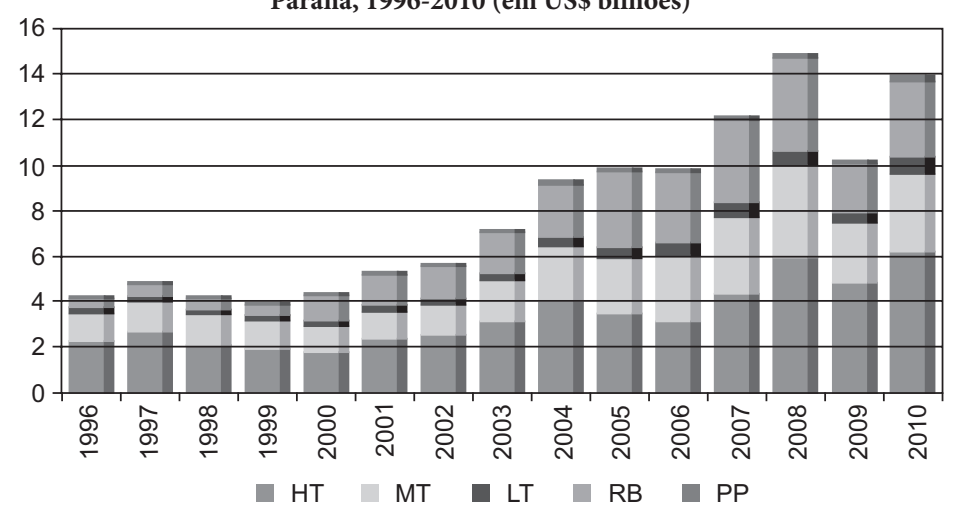

Fonte: Elaboração própria com base em dados de MDIC (2011).

O estado de Pará é o maior exportador da região Norte, com participação de $85 \%$ no total exportado pela região. Suas vendas externas cresceram quase seis vezes ao longo da última década - bem acima da média nacional -, atingindo cerca de U\$ 12,8 bilhões em 2010. Em virtude da crise financeira internacional, as exportações do estado sofreram declínio de aproximadamente 35\% em 2009, acompanhando de perto a tendência nacional. No entanto, o Pará foi um dos estados que tiveram recuperação mais significativa de suas exportações em 2010, com um crescimento de mais de 50\% em relação ao ano anterior. Assim sendo, suas vendas externas nesse ano superam em mais de U\$ 2 bilhões os valores observados em 2008, antes dos efeitos da crise (Gráfico 9).

Gráfico 9 - Exportações por classificação tecnológica,

Pará, 1996-2010 (em US\$ bilhões)



Fonte: Elaboração própria com base em dados de MDIC (2011). 
Quanto à classificação das exportações por conteúdo tecnológico, observa-se forte predominância de manufaturas baseadas em recursos naturais na pauta exportadora do estado. Liderado pelas exportações de minério de ferro, este grupo de produtos representa mais de três quartos das exportações do Pará no final da década. Cabe notar que a expansão das exportações de minério é a principal responsável pelo bom desempenho exportador do estado no período, e provocou significativa elevação na participação de produtos RB na pauta, passando de $34 \%$, em 2000 , para quase $80 \%$ em 2010. Destaque-se ainda que o mesmo elemento também é o principal responsável pela expressiva recuperação das vendas externas após o forte declínio verificado em 2009, posto que mais de $80 \%$ da expansão observada em 2010 é explicada pelo crescimento do grupo de manufaturas baseadas em recursos naturais.

Por fim, deve-se ressaltar a importância do comércio com a China - principal parceiro comercial do estado - para a dinâmica das exportações paraenses nos últimos anos. A grande maioria das exportações de minério de ferro tem a China como destino, e a participação daquele país na pauta teve crescimento expressivo ao longo da década, passando de aproximadamente 5\%, em 2001, para cerca de 30\% em 2010. Ademais, a China teve papel central na trajetória das exportações do Pará após a crise de 2008, pois as vendas para aquele país cresceram mais de $100 \%$ em 2009, ao contrário das exportações para os demais países, que caíram, em média, 22\% naquele ano.

\subsection{CHINA E OS ESTADOS BRASILEIROS: COMPETIÇÃO OU COMPLEMENTARIDADE?}

O índice de competição em exportações (CI), proposto por Blazquez-Lidoy et al. (2006), procura mensurar o grau de similitude entre as pautas exportadoras de dois países ou duas regiões. Tal índice varia de 0 a 1 , e valores mais baixos indicam menor semelhança entre as pautas e, portanto, maior complementaridade entre duas economias.

Nesta subseção, apresentam-se os resultados para o índice de competição em exportações dos estados brasileiros em relação à China, como mais um elemento para avaliar o impacto da expansão chinesa sobre a economia brasileira em uma perspectiva regional.

Os resultados indicam que, em sua maioria, os estados brasileiros apresentam baixo grau de competição com a China. Levando-se em consideração a média no período 2002-2010, os índices de competição em exportações (CI) por unidade da federação variaram entre um mínimo de 0,01 (Tocantins) e um máximo de 0,51 (São Paulo). O índice calculado para o Brasil no mesmo período foi igual a 0,42. Ademais, 17 entre as 27 UFs apresentaram um índice inferior a 0,1, e quatro estados (BA, CE, MG e RJ) 
Gráfico 10 - Índice de competição em exportações,

China $v s$ Brasil e UFs (média 2002-2010)

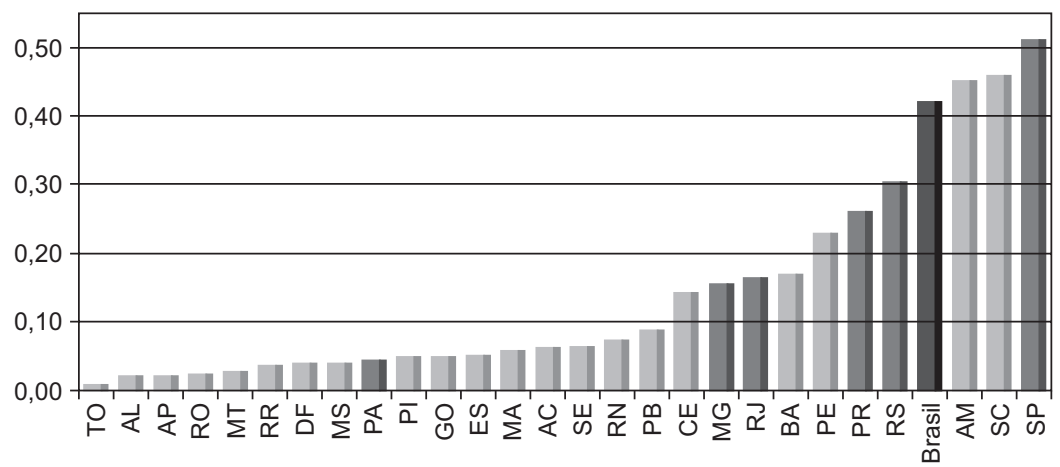

Fonte: Elaboração própria com base em dados de MDIC (2011) e INTRACEN (2011).

tiveram índices entre 0,1 e 0,2 (Gráfico 10). Em apenas três estados (SP, SC e AM), o índice de competição em exportações com a China tem valores relativamente mais elevados, acima da média nacional.

Tais resultados já eram esperados. Como se sabe, a China tem sido um grande produtor e exportador de manufaturas e tem apresentado peso crescente no comércio internacional, principalmente desde sua entrada na OMC no início dos anos 2000. A maior parte das economias estaduais, como exemplificado pelo caso dos principais estados exportadores, descrito na subseção anterior, caracteriza-se em geral por uma pauta exportadora concentrada em produtos de base natural e, portanto, por baixa competição em relação às exportações chinesas.

As principais exceções ocorrem nos três estados cuja pauta de exportação acusa maior presença de manufaturas. O fato de São Paulo ser a unidade da federação em que as exportações mais se aproximam da pauta da China está intimamente ligado ao fato de que o estado apresenta exportações de média e alta tecnologia bem acima da média nacional, como mencionado anteriormente. O mesmo vale para o caso do Amazonas, em decorrência da Zona Franca de Manaus. Por fim, o caso de Santa Catarina se explica pelo fato de que as exportações de bens manufaturados correspondem a mais de $40 \%$ do total estadual, com destaque para máquinas e motores, equipamentos elétricos e eletrônicos, entre outros.

Como mencionado anteriormente, baixos índices sugerem pequena concorrência em relação à China. Assim sendo, pode-se esperar que a maior parte das economias estaduais seja beneficiada pela expansão da economia chinesa, compradora em potencial dos produtos presentes nas pautas de exportação dos estados brasileiros. Tais resultados adquirem grande relevância quando se considera o caso da China, que tem desempenhado papel central na dinâmica do comércio internacional e no crescimento 
da economia mundial nos anos 2000. (Mesquita Moreira, 2007; Blazquez-Lidoy et al., 2006). Por outro lado, os resultados sugerem que os potenciais danos causados pela concorrência com os produtos importados chineses estejam mais concentrados nos estados que apresentam índices mais elevados de competição em exportações com a China: SP, SC, AM, RS e PR.

\section{PERFIL EXPORTADOR, COMÉRCIO COM A CHINA E O CRESCIMENTO DAS ECONOMIAS ESTADUAIS}

Esta seção procura explorar em vários aspectos a relação entre especialização produtiva, comércio internacional e crescimento econômico para os estados brasileiros nos anos 2000, com ênfase nas relações comerciais com a China. Neste sentido, dois elementos serão enfatizados. Em primeiro lugar, investiga-se os efeitos imediatos da crise financeira internacional iniciada em 2008, particularmente sobre os níveis das exportações estaduais. Em segundo lugar, examina-se a correlação entre o crescimento econômico dos estados ao longo da década e dois indicadores de especialização produtiva, a saber: (i) os índices de qualidade das exportações QSit e QKit, que refletem o conteúdo tecnológico das exportações segundo Lall (2000); e (ii) os índices de competição em exportações com a China, mencionados na seção anterior.

É sabido que a crise financeira de 2008 trouxe impactos negativos generalizados sobre as exportações do Brasil, acompanhando tendência verificada em nível mundial. Em 2009, as exportações brasileiras observaram um declínio de aproximadamente 35\%. Embora a queda nas vendas externas tenha atingido todos os grupos por conteúdo tecnológico, as maiores quedas ocorreram na exportação de manufaturas de média e alta tecnologia ( $-60,1 \%$ e $-37,6 \%$, respectivamente).

Como já mencionado anteriormente, as exportações brasileiras tiveram expansão significativa em 2010, recuperando os níveis observados antes da crise. No entanto, a evolução das exportações por conteúdo tecnológico sugere que tal recuperação não foi homogênea entre todos os grupos. Em particular, a maior expansão foi observada nas exportações de manufaturas baseadas em recursos naturais, que em 2010 cresceram $53 \%$ em relação ao ano anterior.

A evolução das exportações por conteúdo tecnológico entre 2008 e 2010 se reflete no desempenho das exportações estaduais durante o período. Nesse caso, verifica-se que os estados que sentiram mais fortemente os efeitos da desaceleração da economia mundial e que têm observado maior dificuldade para recuperar os níveis de exportação pré-crise são aqueles cuja pauta exportadora é relativamente mais diversificada e sofisticada, com maior participação de produtos manufaturados. Por outro lado, entre os maiores estados exportadores, aqueles cuja recuperação foi mais acentuada em 2010 
Gráfico 11 - Variação das exportações, Brasil e principais UFs, 2009-2010 (em \%)

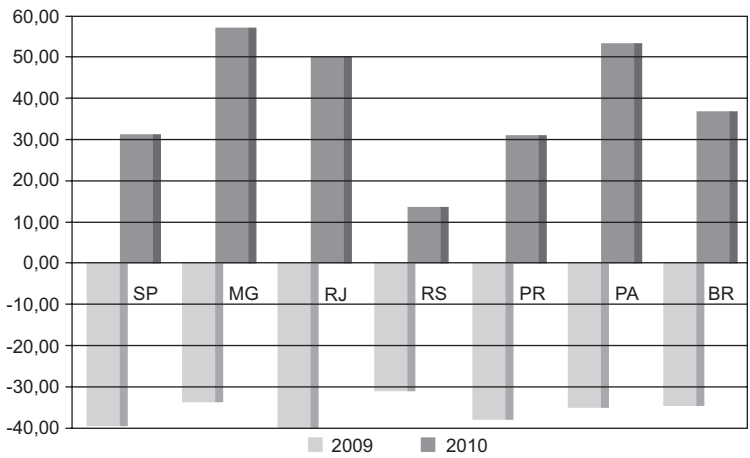

Fonte: Elaboração própria com base em dados de MDIC (2011).

são precisamente os que exportam majoritariamente produtos primários ou manufaturas baseadas em recursos naturais: MG, PA e RJ.

Assim, em uma análise preliminar, parece haver uma associação muito bem definida entre o perfil da pauta de exportações e a variação dos valores exportados entre 2008 e 2010. A questão seguinte passa a ser sobre o papel desempenhado pela China durante esse período. Ou seja, em que medida a competição ou complementaridade das economias dos diversos estados em relação à China explica o desempenho das exportações estaduais após a crise de 2008? Para responder a esta pergunta, avaliouse a correlação entre os índices de competição em exportações (CI) dos principais estados em relação à China e o resultado líquido das variações no total exportado entre 2008 e $2010^{6}$.

O Gráfico 12 ilustra tal correlação. Os resultados sugerem, como esperado, que os estados com maior complementaridade em relação à economia chinesa recuperaram mais intensamente o nível de suas exportações em 2010, o que pode ser explicado pelo fato de que a China recuperou suas taxas de crescimento econômico (e, portanto, sua demanda por importações) mais rapidamente que outros parceiros comerciais importantes do Brasil, como Estados Unidos e União Europeia. Outra constatação interessante nos resultados é que parece haver uma espécie de limiar que divide os estados brasileiros entre aqueles que recuperaram em 2010 os níveis de exportação pré-crise e aqueles que não o fizeram. Como pode ser visto no gráfico, todos os estados cujo índice de competição com a China é inferior a 0,2 se enquadram no primeiro grupo, ao passo que aqueles com índices acima de 0,2 fazem parte do segundo grupo.

\footnotetext{
${ }^{6}$ Este resultado foi calculado simplesmente como a soma dos percentuais de variação das exportações em 2009 e 2010 para cada estado. Valores negativos, nesse caso, indicam que a recuperação verificada em 2010 não foi suficiente para compensar a queda observada em 2009.
} 
Gráfico 12 - Índice de competição e evolução das exportações, principais UFs, 2009-2010

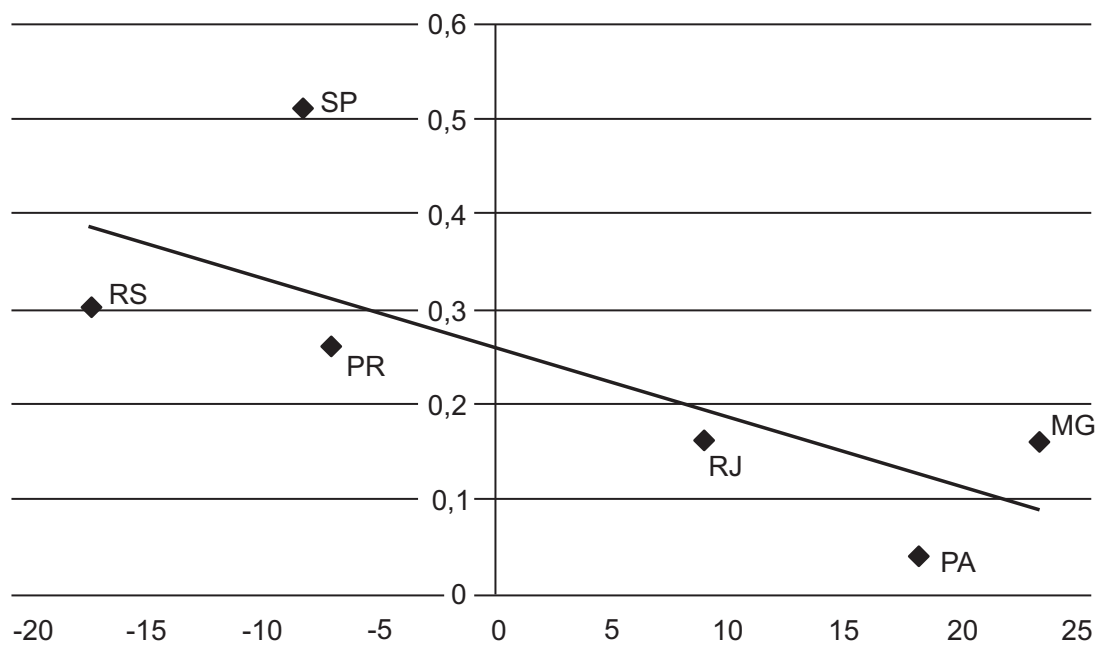

Fonte: Elaboração própria com base em dados de MDIC (2011).

Uma das questões centrais propostas por esse trabalho diz respeito à relação entre especialização produtiva, comércio com a China e crescimento econômico dos estados brasileiros. Com o intuito de elucidar tal relação, foram avaliadas medidas de correlação entre os índices de qualidade da pauta de exportação $(Q S$ e $Q K)$ e as taxas de crescimento das principais economias estaduais nos anos 2000.

Os Gráficos 13 e 14 resumem os resultados. O primeiro mostra a relação entre a qualidade das exportações - medida pela média do índice de qualidade das exportações na especificação schumpeteriana (QS) no período 2000-2009 - e a taxa média de crescimento anual dos estados no mesmo período. O gráfico de dispersão sugere uma relação negativa entre essas duas variáveis, ao contrário do esperado pela teoria. O cálculo do coeficiente de correlação entre as duas séries confirma tal resultado, pois assume um valor negativo, igual a $-0,52$.

O Gráfico 14, por sua vez, enfatiza o papel do setor manufatureiro para o crescimento econômico, e mostra uma relação negativa entre a média do índice de qualidade das exportações na especificação kaldoriana $(Q K)$ e o desempenho das maiores economias estaduais no período 2000-2009. Também nesse caso, os resultados contradizem as predições da teoria ao mostrar que taxas mais altas de crescimento tenderam a ocorrer nos estados com uma estrutura produtiva e exportadora menos diversificada e com maior peso de produtos de base natural. O cálculo do coeficiente de correlação segue a mesma direção, indicando um valor negativo, igual a $-0,68$.

Cabe notar que este resultado está em desacordo com a teoria kaldoriana e também contradiz estudos empíricos, como o de Lederman e Maloney (2007), que encontram 
Gráfico 13 - Qualidade das exportações e crescimento, principais UFs, 2000-2009

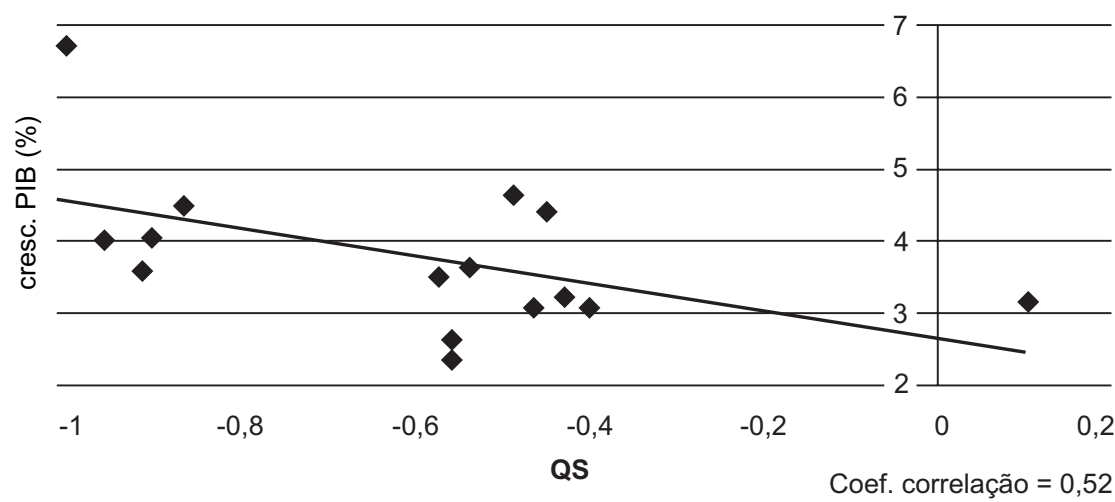

Fonte: Elaboração própria com base em dados de IBGE (2011) e MDIC (2011).

Gráfico 14 - Qualidade das exportações e crescimento, principais UFs, 2000-2009

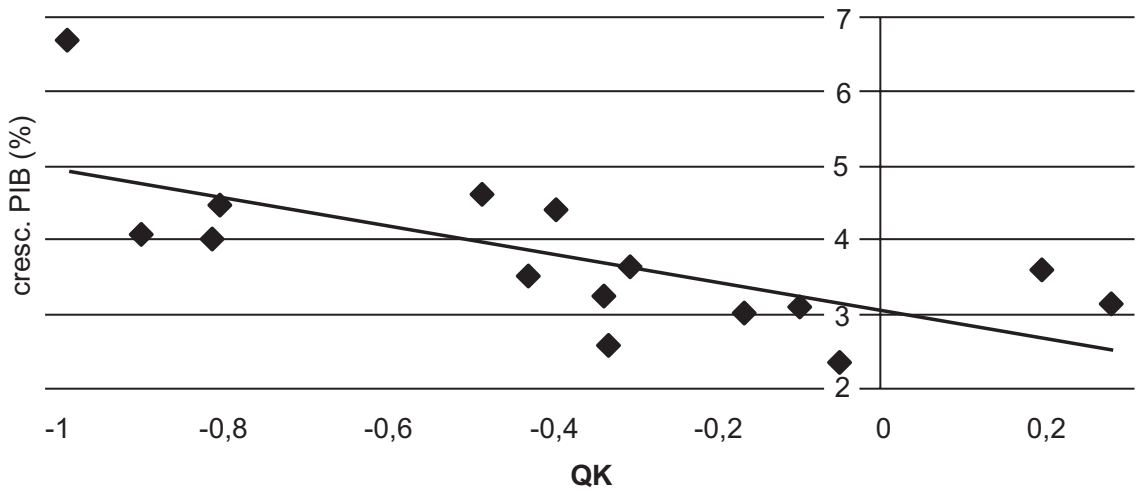

Fonte: Elaboração própria com base em dados de IBGE (2011) e MDIC (2011).

uma relação negativa entre a concentração das exportações em produtos de base natural e o crescimento econômico.

Uma possível explicação para tais resultados diz respeito ao boom de commodities observado ao longo dos anos 2000, liderado pelas importações de matérias-primas pela China. Esse é um dos principais aspectos analisados neste paper, e, para elucidar tal questão, foi avaliado o perfil da pauta de exportações dos estados brasileiros, em comparação aos da China, e sua relação com o crescimento das economias estaduais no período recente. Nesse caso, busca-se examinar em que medida os estados tendem a se beneficiar da expansão da segunda maior economia do mundo ou sofrer concorrência dessa mesma economia na disputa por mercados de exportação e os possíveis efeitos sobre seu desempenho econômico. 
Como mencionado na seção anterior, a maioria dos estados brasileiros apresentam valores relativamente baixos para os índices de competição em exportações (Blazque-Lidoy et al., 2006) e, portanto, encontram-se em posição relativamente favorável em relação à complementaridade com a economia da China (Gráfico 10). Assim sendo, a expansão chinesa e o seu peso crescente no comércio internacional dos estados brasileiros ao longo da última década poderiam explicar os resultados atípicos (segundo a teoria) descritos anteriormente.

Ao se analisar a relação entre os coeficientes de competição em exportações com a China e o crescimento médio das maiores economias estaduais no período 2000-2009, no entanto, observa-se correlação negativa, o que sugere - como esperado - que o grau de complementaridade em relação à economia chinesa desempenhou papel preponderante na dinâmica de crescimento dos estados brasileiros nesse período (Gráfico 15). Ou seja, os resultados indicam que aqueles estados cuja pauta de exportação é complementar à pauta chinesa apresentaram maiores taxas de crescimento entre 2000 e 2009. Cabe notar que tal resultado corrobora outros estudos que tentaram captar a influência do crescimento da China sobre a América Latina (Jenkins et al., 2008; Mesquita Moreira, 2007) e sobre a economia de Minas Gerais (Libânio, 2008).

Este resultado sugere que a dinâmica de crescimento dos estados brasileiros na década de 2000 foi condicionada pela expansão da China e a complementaridade de sua economia com as economias estaduais, o que implicou em uma demanda crescente pelos produtos de exportação dos estados. Cabe notar que tal influência parece ter sido forte o bastante para inverter um fato estilizado do desenvolvimento econômico (apoiado por teorias de inspiração kaldoriana e schumpeteriana) de que economias

Gráfico 15 - CI da China e crescimento, UFs selecionadas, 2000-2009

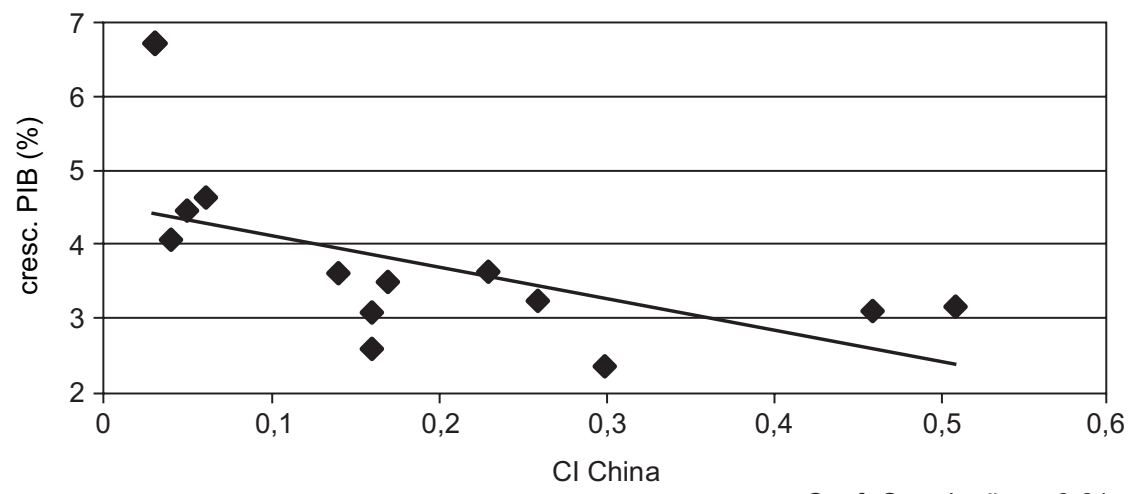

Coef. Correlação $=-0,61$

Fonte: Elaboração própria com base em dados de INTRACEN (2011), IBGE (2011) e MDIC (2011). 
mais diversificadas e com maior conteúdo tecnológico em suas exportações tendem a apresentar taxas mais elevadas de crescimento.

Uma possível explicação para tal resultado é a grande expansão da demanda chinesa por commodities, que provocou expressiva alta nos preços e nas exportações desses produtos no mercado internacional, e beneficiou regiões produtoras de bens primários e manufaturas baseadas em recursos naturais.

\section{CONSIDERAÇÕES FINAIS:}

Este trabalho procurou examinar o papel da China nas trajetórias regionais de crescimento durante o período 1996-2009. A principal hipótese avaliada nesta pesquisa é de que estados exportadores de commodities seriam os mais beneficiados pela elevação da demanda e dos preços internacionais ao longo da última década.

Alguns dos principais elementos desenvolvidos no trabalho foram a descrição das pautas de exportação por intensidade tecnológica dos principais estados exportadores do Brasil, o cálculo dos coeficientes de especialização produtiva dos estados, em comparação à China, e uma análise empírica da relação entre padrões de especialização e crescimento econômico dos estados.

Os efeitos da crise financeira de 2008 sobre os estados da região foram também examinados neste artigo, particularmente no que se refere ao declínio das exportações dos estados em 2009 e a posterior recuperação observada em 2010. Os resultados encontrados sugerem uma associação muito bem definida entre essa variável e o perfil da pauta exportadora, indicando que a evolução das exportações estaduais após a crise financeira internacional foi mais favorável aos estados exportadores de produtos primários e manufaturas baseadas em recursos naturais.

Quanto à relação entre especialização produtiva, comércio Brasil-China e crescimento - foco central deste trabalho -, os resultados sugerem que o crescimento econômico dos estados brasileiros no período recente foi influenciado positivamente pela participação de produtos de base natural no total exportado e pela complementaridade em relação à pauta de exportações da China.

O presente estudo aborda várias questões pouco exploradas na literatura. Algumas de suas principais contribuições são a análise dos padrões de especialização em nível sub-nacional, e sua relevância para a performance recente das economias. Por outro lado, embora a classificação proposta por Lall (2000) tenha sido aplicada para vários países, ainda não há estudos similares na literatura a respeito de perfil exportador de Estados e regiões. Da mesma forma, a metodologia proposta por Blazquez-Lidoy et al. (2006) não foi usada em nível subnacional. Assim, o foco sobre os impactos regionais das flutuações da economia mundial é a principal contribuição original deste trabalho. 
Os resultados encontrados neste estudo são diferentes do esperado pela literatura teórica, e são justificados pela especificidade da relação Brasil-China no período analisado. Resta saber se o crescimento dos estados brasileiros na década de 2000 seguiu um padrão atípico, que tende a ser revertido no futuro próximo, ou se a expansão chinesa continuará por muito tempo promovendo ganhos para as economias estaduais menos diversificadas e concentradas na exportação de produtos de base natural.

\section{REFERÊNCIAS}

BLAZQUEZ-LIDOY, J.; RODRIGUEZ, J.; SANTISO, J. Angel or Devil? China's trade impact on Latin American emerging markets. OECD Development Centre Working Paper, OECD, n. 252, 2006.

DIXON, R.; THIRLWALL, A. P. A model of regional growth rate differences on Kaldorian lines. Oxford Economic Papers, v. 27, p. 201-14, 1975.

DOSI, G.; PAVITT, K.; SOETE, L. The economics of technical change and international trade. Londres: Harvester Wheatsheaf, 1990.

FAGERBERG, J. Technology and international differences in growth rates. Journal of Economic Literature, v. 32, n. 3, p. 1147-1175, 1994.

INSTITUTO BRASILEIRO DE GEOGRAFIA E ESTATÍSTICA (IBGE). Contas Regionais do Brasil 2005-2009. Rio de Janeiro: IBGE, 2011.

INTERNATIONAL TRADE CENTER (INTRACEN). ITC By Country. Trade and Investment Data. Intracen, 2011. Disponível em: <www.intracen.org>. Acesso em: 20 mai. 2012.

JENKINS, R.; PETERS, E.; MOREIRA, M. The impact of China on Latin America and the Caribbean. World Development, v. 36, n. 2, p. 235-253, 2008.

KALDOR, N. Causes of the Slow Rate of Economic Growth of the United Kingdom: an Inaugural Lecture. Cambridge: Cambridge University Press, 1966.

KALDOR, N. The case for regional policies. Scottish Journal of Political Economy, v. 17, issue 3, p.337-348, 1970.

LALL, S. The technological structure and performance of developing country manufactured exports, 1985-1998. Oxford Development Studies, v. 28, n. 3, p. 337-369, 2000.

LALL, S.; WEISS, J. China's competitive threat to Latin America: an analysis for 1990-2002. Oxford Development Studies, v. 33, n. 2, p. 163-194, 2005.

LEDERMAN, D.; MALONEY, W. Trade structure and growth. In NEWFARMER, R.; SHAW, W.; WALKENHORST, P. (Eds.) Breaking Into New Markets. Washington DC: The World Bank, 2007.

LIBANIO, G. O. crescimento da China e seus impactos sobre a economia mineira. In SEMINÁRIO SOBRE A ECONOMIA MINEIRA, 8, Diamantina, ago. 2008, Anais..., 2008. 
MESQUITA MOREIRA, M. Fear of China: is there a future for manufacturing in Latin America? World Development, v. 35, n. 3, p. 355-376, 2007.

MINISTÉRIO DO DESENVOLVIMENTO, INDÚSTRIA E COMÉRCIO EXTERIOR (MDIC). ALICEWeb. 2011. Disponível em: <http://aliceweb2.mdic.gov.br>. Acesso em: 20 mai. 2012.

ROS, J. Trade specialization and economic growth. In: FANELLI, J.; MEDHORA R., (Eds.) Finance and competitiveness in developing countries. New York: Routledge, 2002.

UNITED NATIONS CONFERENCE ON TRADE AND DEVELOPMENT (UNCTAD). Trade and Development Report 2009. New York and Geneva: United Nations, 2009.

YOUNG, A. Increasing returns and economic progress. Economic Journal, December, 1928. 